Article

\title{
Exploration of an Extracellular Polymeric Substance from Earthworm Gut Bacterium (Bacillus licheniformis) for Bioflocculation and Heavy Metal Removal Potential
}

\author{
Jayanta Kumar Biswas ${ }^{1,2, *}$, Anurupa Banerjee ${ }^{1}$, Binoy Sarkar ${ }^{3}{ }^{\mathbb{D}}$, Dibyendu Sarkar ${ }^{4, *}$ (D), \\ Santosh Kumar Sarkar ${ }^{5}$, Mahendra Rai ${ }^{6}$ and Meththika Vithanage ${ }^{7}$ \\ 1 Enviromicrobiology, Ecotoxicology and Ecotechnology Research Unit, Department of Ecological Studies, \\ University of Kalyani, Kalyani, Nadia 741235, West Bengal, India; anu.banerjee90@gmail.com \\ 2 International Centre for Ecological Engineering, University of Kalyani, Kalyani 741235, West Bengal, India \\ 3 Lancaster Environment Centre, Lancaster University, Lancaster LA1 4YQ, UK; b.sarkar@lancaster.ac.uk \\ 4 Department of Civil, Environmental and Ocean Engineering, Stevens Institute of Technology, 1 Castle Point \\ on Hudson, Hoboken, NJ 07030, USA \\ 5 Department of Marine Science, University of Calcutta, 35, Ballygunge Circular Road, Kolkata 700019 , \\ West Bengal, India; sarkar.santosh@gmail.com \\ 6 Department of Biotechnology, SGB Amravati University, Amravati 444602, Maharashtra, India; \\ pmkrai@hotmail.com \\ 7 Office of the Dean, Faculty of Applied Sciences, University of Sri Jayewardenepura, Nugegoda 10250, \\ Sri Lanka; meththikavithanage@gmail.com \\ * Correspondence: biswajoy2008@gmail.com (J.K.B.); dsarkar@stevens.edu (D.S.)
}

Received: 7 November 2019; Accepted: 30 December 2019; Published: 3 January 2020

\begin{abstract}
The present study shows the potential of an extracellular polymeric substance (EPS) produced by Bacillus licheniformis strain KX657843 isolated from earthworm (Metaphire posthuma) gut in the sorption of $\mathrm{Cu}$ (II) and $\mathrm{Zn}$ (II) and in flocculation. After harvesting bacterial cells from sucrose supplemented denitrifying culture medium, the EPS was extracted following ethanolic extraction method. The Fourier Transform Infrared Spectroscopy (FTIR) and ${ }^{1} \mathrm{H}$ and ${ }^{13} \mathrm{C}$ Nuclear Magnetic Resonance (NMR) of EPS revealed its functional groups, electronegative constituents, unsaturated carbon, and carbonyl groups. The negatively charged functional groups of carbohydrates and protein moiety of the EPS endowed it with heavy metal binding capacity through electrostatic interactions. The highest flocculation activity (83\%) of EPS was observed at $4 \mathrm{mg} \mathrm{L}^{-1}$ and $\mathrm{pH} 11$. The metal sorption by EPS increased with increasing $\mathrm{pH}$. At $\mathrm{pH}$ 8, the EPS was able to remove 86 and $81 \%$ $\mathrm{Cu}(\mathrm{II})$ and $\mathrm{Zn}(\mathrm{II})$, respectively, from a $25 \mathrm{mg} \mathrm{L}^{-1}$ metal solution. $94.8 \%$ of both the metals at $25 \mathrm{mg}$ $\mathrm{L}^{-1}$ metal solutions were removed by EPS at EPS concentration of $100 \mathrm{mg} \mathrm{L}^{-1}$. From Langmuir isotherm model, the maximum sorption capacities of EPS were calculated to be $58.82 \mathrm{mg} \mathrm{g}^{-1}$ for $\mathrm{Cu}$ (II) and $52.45 \mathrm{mg} \mathrm{g}^{-1}$ for $\mathrm{Zn}$ (II). The bacterial EPS showed encouraging flocculating and metal sorption properties. The potential to remove $\mathrm{Cu}(\mathrm{II})$ and $\mathrm{Zn}(\mathrm{II})$ implies that the EPS obtained from the earthworm gut bacteria can be used as an effective agent for environmental remediation of heavy metals and in bioflocculation.
\end{abstract}

Keywords: extracellular polymeric substances; earthworm; gut bacteria; flocculation; metal remediation; isotherm models 


\section{Introduction}

Soil is the soul of infinite life forms ranging from miniscule microbes to macro-invertebrates. The latter groups are represented by earthworms, termites and ants, which are distinguished by their capacity to excavate the soil and produce a great impact on soil physical properties by creating organomineral structures, such as macro-voids, nests, mounds, galleries and caverns. These organisms have been described as "ecological engineers" of the soil [1]. Earthworms play a pivotal role in decomposition, nutrient cycling and maintenance of soil structure in the terrestrial ecosystem [2]. The gut of the earthworm constitutes an anoxic and organic substrate-rich microzone which provides a unique opportunity to the ingested heterotrophic soil bacteria for anaerobiosis [3]. The earthworm's alimentary tract provides a compelling environment to the gut associated microorganisms, and microorganisms experience a continuous change in the $\mathrm{pH}$, salinity, nutrient levels and gases like oxygen, nitrogen, hydrogen etc. which can influence the production of extracellular polymeric substances (EPS) or biofilm by gut-inhabiting microorganisms [4].

EPS are a complex blend of high molecular weight microbial biopolymeric secretory by-products. These biopolymers mostly consist of proteins, polysaccharides, uronic acids, humic substances, lipids, and nucleic acids [5]. Synthesis of EPS and their composition are regulated by a variety of environmental conditions especially the nutrient level including the availability of carbon and nitrogen in the growth medium [6]. These EPS show unique physiological and physicochemical properties which make them suitable for several clinical, industrial and environmental applications $[7,8]$. Biopolymers have been recognized by many researchers as potential alternatives to conventional chemical polymers because of their ease of biodegradability, high efficiency, and non-toxic nature [9]. Microbial EPS offer an array of promises for their applications in foods, drug delivery, oil recovery, water purification, and metal removal in mining and industrial waste treatments, and also in downstream processes in fermentation and pharmaceutical industries [10].

In wastewater treatment and downstream processing industries, flocculating agents are used in the process of removing colloids, suspended solids and cell debris comprising main constituents of wastewater [11]. Synthetic polymers like acrylamide, acrylic acid and mixtures of their derivatives are oft-used flocculants for such treatments [12]. However, reports on some of these synthetic flocculants show their neurotoxic and carcinogenic effects, including disorders like neuropathies, ataxia, numbness of hands and feet, muscle weakness, and in some cases cerebellar alterations even at a sub-chronic concentration [13]. Hence, it is important to develop non-toxic, environmental-friendly, cost-effective and highly efficient flocculating agents for wastewater treatment. In this scenario, bioflocculants endowed with attributes of biodegradability, non-toxicity and eco-friendly nature are gaining importance [14]. EPS produced by microorganisms could be a promising alternative to the chemically synthesized flocculants [11].

Recently the extensive usage of various heavy metal (e.g., $\mathrm{Cu}, \mathrm{Zn}, \mathrm{Cd}, \mathrm{Cr}, \mathrm{Pb}, \mathrm{Ni}, \mathrm{Co}$ ) compounds in different industries has led to their increase in ecosystems [15]. Heavy metals are nonbiodegradable in nature, and as a result they persist in the environment for longer periods of time. Conventional treatment processes for the remediation of heavy metal ions include coagulation, chemical precipitation, electrodialysis, evaporative recovery, floatation, flocculation, ion exchange, nanofiltration, reverse osmosis and ultrafiltration [16]. Although effective, these methods are often highly expensive and result in the production of a huge amount of ineradicable toxic slurries which again pollutes the environment. Therefore, there is a need for an effective yet less expensive, environmentally safe method to minimize heavy metals from toxic to safe limits in the environment [17]. Recently, biological methods, including prokaryotic as well as eukaryotic microbial cells and their by-products like bacterial EPS, are used as emerging candidates for the biosorption and remediation of heavy metals at contaminated sites in an eco-friendly fashion $[18,19]$. Thus, utilizing bacterial EPS in environmental management is an emerging area of research. Previous studies report an L-asparagine monohydrate dependent EPS producing Bacillus licheniformis from the gut of the earthworm, Metaphire posthuma, and the modulating factors for microbial synthesis of EPS [4]. Since such bacterium harbors in the gut of the earthworm 
which is highly acclaimed as a soil fertility enhancing and bioremediating organism and, in concert with other bacterial assemblage, it aids the earthworm gut acting as a bioreactor. The study on the role of the EPS synthesized by that bacterium in environmental management deserves special attention.

The particular gut isolate Bacillus licheniformis KX657843 has been tested for certain properties such as metal removal, phosphate solubilization, indole acetic acid (IAA) production, and its effect on seed germination has also been reported [20]. The present study focuses on studying the metal sorption and bioflocculating properties of the EPS produced by Bacillus licheniformis KX657843. Two main objectives of the present study are the following: (1) characterization of the EPS by Nuclear Magnetic Resonance (NMR) and Mass Spectroscopy (MS) while the Fourier transform infrared spectroscopy (FTIR) study of the EPS was done earlier [4], (2) examining the effects of some fundamental parameters on the sorption of heavy metal $\mathrm{Cu}(\mathrm{II})$ and $\mathrm{Zn}$ (II) and flocculation by the EPS obtained from Bacillus licheniformis.

\section{Materials and Methods}

\subsection{Earthworm Sample}

Earthworms (Metaphire posthuma) used in this study were of medium size $(\sim 10 \mathrm{~cm}$ in length and $5 \mathrm{~mm}$ in diameter), endogeic, and geophagous organism. Sterile bags were used for collecting the earthworm samples from the garden soil of University of Kalyani campus (Lat 22.9862 ${ }^{\circ} \mathrm{N}$, Long $88.4464^{\circ}$ E). Further examination and isolation of bacteria were carried out from these earthworm samples.

\subsection{Isolation and Characterization of the Microorganism}

The isolation procedure of the bacteria from the gut of the earthworm Metaphire posthuma with a characteristic slimy, mucoid phenotypic nature (Supplementary information: Figure S1) and the detailed biochemical and molecular level identification have been previously reported [4,20]. Bacillus licheniformis strain (KX657843) able to produce EPS exclusively in the presence of L-asparagine monohydrate was isolated from the earthworm gut. The information regarding the biochemical characterization and the complete $16 \mathrm{~S}$ rRNA gene sequencing analysis has been reported in previous works $[4,20]$.

\subsection{Production of EPS}

EPS was extracted from the bacterial isolates employing an ethanolic extraction method [21]. Mucoid colonies obtained from $24 \mathrm{~h}$ cultures on plates of denitrifying agar medium supplemented with sucrose instead of citrate were scraped with a sterile glass slide and re-suspended in a sterile saline solution $(0.85 \% \mathrm{NaCl})$. Sucrose was utilized since maximum amount of EPS was produced when sucrose was the carbon source. From the resulting suspension, cells were harvested by centrifugation at $9500 \times \mathrm{g}$ for $30 \mathrm{~min}$ at $4{ }^{\circ} \mathrm{C}$. The precipitation of the resultant supernatant was done by adding an equal volume of pre-chilled absolute ethanol and incubated the mixture at $-20^{\circ} \mathrm{C}$ for $1 \mathrm{~h}$. Precipitated EPS was recovered by centrifugation at $9500 \times g$ for $20 \mathrm{~min}$ at $4{ }^{\circ} \mathrm{C}$. Finally, the pellet obtained in the process was dialyzed against Milli $Q$ water using cellulose membrane (14 KDa MWCO membrane) for $72 \mathrm{~h}$ employing two changes of Milli $\mathrm{Q}$ water per day in order to remove low molecular weight impurities including ethanol, and then the solution was dried using vacuum freeze drier [22].

\subsection{Characterization of EPS}

The purified EPS fraction was subjected to FTIR analysis using potassium bromide (KBr) disc method in order to study the functional groups. The EPS sample (2-5 mg) was mixed with $\mathrm{KBr}$ of IR spectroscopy grade in a smooth agate mortar. The mixture was then pressed under pressure of about 5-8 ton $\mathrm{cm}^{-2}$ for about 20-30 s [4,23]. The electrical charge on EPS was determined by electrophoresis method using dynamic light scattering in combination with an applied electric field [24]. The ${ }^{1} \mathrm{H} N \mathrm{NR}$ and ${ }^{13} \mathrm{C}$ NMR analyses were conducted in $\mathrm{D}_{2} \mathrm{O}$ solvent. To obtain ${ }^{1} \mathrm{H}$ NMR spectra, EPS sample $(0.7$ $\mathrm{mL}$ ) was dissolved in $\mathrm{D}_{2} \mathrm{O}$, and a solution of tetramethylsilane (TMS) was used as the reference internal 
standard. The ${ }^{1} \mathrm{H}$ NMR and ${ }^{13} \mathrm{C}$ NMR spectra were recorded at 500 and $125.7 \mathrm{MHz}$, respectively. Mass spectra were collected with a JEOLJMS-AX 500 spectrophotometer.

\subsection{Determination of Flocculation Activity}

The flocculation activity was determined using an artificial colloidal suspension made of kaolin clay. In terms of surface charge behavior, the kaolin clay mimics wastewater sludge (zeta potential = $-32 \mathrm{mV}$ ) [25] and provides better reproducible results than the sludge itself in terms of suspension stability. The flocculation activity was determined following a method described earlier [26] with minor modifications. Kaolin clay suspension $\left(5 \mathrm{~g} \mathrm{~L}^{-1}, \mathrm{pH}=7\right)$ in $1 \% \mathrm{w} / \mathrm{v}$ aqueous $\mathrm{CaCl}_{2}$ with EPS as the test bioflocculant was thoroughly vortexed for $1 \mathrm{~min}$, and was kept at room temperature for $5 \mathrm{~min}$. The EPS concentrations were varied in the range of $2-20 \mathrm{mg} \mathrm{L}^{-1}$. The entire mixture was prepared to a final volume of $20 \mathrm{~mL}$ in test tubes. Finally, the optical density of the aqueous phase was measured with a spectrophotometer (UV-1800 UV-Vis Shimadzu, Kyoto, Japan) at $550 \mathrm{~nm}$ wavelength. A control treatment was set up in a similar way where extracted EPS was replaced with distilled water. Flocculation activity was determined by the following equation

$$
\text { Flocculation activity }(\%)=\frac{\mathrm{B}-\mathrm{A}}{\mathrm{B}} \times 100
$$

where, A is optical density of samples containing EPS, and B is the optical density of the control [9].

\subsection{Effect of Operational Parameters on Flocculation Activity}

The concentration/dosage of EPS that gave the best result in the above flocculation experiment was chosen for subsequent experiments, and the flocculation activities under different operational parameters were determined independently by the method mentioned above. All the experiments employed triplicate sets.

The effect of $\mathrm{pH}$ on flocculation activity was assessed by adjusting the $\mathrm{pH}$ of the flocculant mixture at a $\mathrm{pH}$ range of $5-12$ using $1 \mathrm{~N} \mathrm{HCl}$ and $1 \mathrm{~N} \mathrm{NaOH}$. The effect of different concentrations of $\mathrm{CaCl}_{2}$ on the flocculation activity was determined by varying the salt concentrations from 0 to $8 \%$. Here, two different $\mathrm{pH}$ conditions were chosen: the neutral $\mathrm{pH}$ (7.0) and the $\mathrm{pH}$ (11.0) which gave the best flocculation activity in the $\mathrm{pH}$ effect experiment stated above. The effect of different cations on the flocculation activity was assessed by replacing $\mathrm{CaCl}_{2}$ with $\mathrm{Na}^{+}, \mathrm{K}^{+}, \mathrm{Cu}^{2+}, \mathrm{Zn}^{2+}$ and $\mathrm{Fe}^{3+}$ at $1 \% \mathrm{w} / \mathrm{v}$ concentration. Thermal stability of the flocculant EPS was determined by incubating the EPS in water bath at a temperature range of $50-100{ }^{\circ} \mathrm{C}$ for $30 \mathrm{~min}$ at neutral as well as the $\mathrm{pH}$ which gave the best flocculation activity in the $\mathrm{pH}$ effect experiment.

\subsection{Determination of $\mathrm{Cu}(\mathrm{II})$ and $\mathrm{Zn}(\mathrm{II})$ Adsorption Efficiency}

Stock solutions $(500 \mathrm{mM})$ of $\mathrm{Cu}^{2+}$ and $\mathrm{Zn}^{2+}$ were prepared by dissolving $\mathrm{CuSO}_{4} \cdot 5 \mathrm{H}_{2} \mathrm{O}$ and $\mathrm{ZnSO}_{4} \cdot 7 \mathrm{H}_{2} \mathrm{O}$, respectively, in Milli $\mathrm{Q}$ water, and passed through $0.45 \mu \mathrm{m}$ pre-sterile syringe filters (Millipore filter paper). A stock solution of EPS $\left(1000 \mathrm{mg} \mathrm{L}^{-1}\right)$ was also prepared using milli Q water. The batch adsorption system consisted of a total $30 \mathrm{~mL}$ of EPS and heavy metal solutions both at $25 \mathrm{mg}$ $\mathrm{L}^{-1}$ concentrations. The $\mathrm{pH}$ of the solutions was adjusted using $1 \mathrm{~N} \mathrm{HCl}$ and $1 \mathrm{~N} \mathrm{NaOH}$ at a range of 5-8 keeping the concentrations of EPS and heavy metal ions constant. All experiments were conducted in triplicates, and a setup without EPS was treated as control. The suspensions were agitated on a shaker at $25 \pm 2{ }^{\circ} \mathrm{C}$ at $150 \mathrm{rpm}$ for $24 \mathrm{~h}$. An aliquot of $6 \mathrm{~mL}$ from the batch suspensions was withdrawn, to which equal volume of ice-cold ethanol was added, and the suspension was centrifuged at $1000 \times$ $g$ for $10 \mathrm{~min}$ [27]. The supernatant obtained was filtered through $0.45 \mu \mathrm{m}$ syringe filter and further acid digested at $100{ }^{\circ} \mathrm{C}$ on hot plate with $1 \mathrm{~mL}$ concentrated $\mathrm{HCl}$ in order to remove any organic impurities which would otherwise interfere in the measurement of metal ions. Then the amount of residual metal ions remaining in the digested supernatants, both in the EPS treated and EPS free control, was determined using atomic absorption spectroscopy (AAS) (AAnalyst 200, PerkinElmer, 
Waltham, MA, USA). A calibration was performed using individual standard reference solutions (Fluka Analytical, Buchs St. Gallen, Switzerland) for ensuring the quality control. The standard curve has been provided in (Supplementary information: Figure S2). The concentration range for both the metal ions taken was from $0-2 \mathrm{mg} \mathrm{L}^{-1}$. The correlation coefficients $\left(\mathrm{R}^{2}\right)$ for $\mathrm{Cu}(\mathrm{II})$ and $\mathrm{Zn}$ (II) were 0.992 and 0.991 respectively.

\subsection{Adsorption Isotherm}

Adsorption isotherms of $\mathrm{Cu}(\mathrm{II})$ and $\mathrm{Zn}$ (II) on the extracted EPS were studied by varying the EPS concentrations from 0 to $100 \mathrm{mg} \mathrm{L}^{-1}(\mathrm{pH}=7.0$ ) while keeping $\mathrm{Cu}$ (II) and $\mathrm{Zn}$ (II) concentrations constant at $25 \mathrm{mg} \mathrm{L}^{-1}$. Other process parameters were similar as the above. The adsorption of $\mathrm{Cu}(\mathrm{II})$ and $\mathrm{Zn}$ (II) by EPS was tested using the linear Langmuir isotherm model represented by the equation given below:

$$
\frac{C_{e}}{q}=\frac{C_{e}}{q_{m}}+\frac{1}{q_{m} b}
$$

where, $\mathrm{q}$ represents the uptake of metal by EPS $\left(\mathrm{mg} \mathrm{g}^{-1}\right)$ calculated by the formula given below (Equation (3)), $\mathrm{C}_{\mathrm{e}}$ is the metal ion concentration at equilibrium $\left(\mathrm{mg} \mathrm{L}^{-1}\right), \mathrm{q}_{\mathrm{m}}\left(\mathrm{mg} \mathrm{g}^{-1}\right)$ and $\mathrm{b}\left(\mathrm{L} \mathrm{mg}^{-1}\right)$ are the Langmuir constants, which determines the maximum metal adsorption capacity and the affinity between the biosorbent and the metal ion, respectively. The constants are determined from the linear plot of $C_{e} / q$ versus $C_{e}$.

$$
\mathrm{q}=\frac{\mathrm{V}\left(\mathrm{C}_{\mathrm{i}}-\mathrm{C}_{\mathrm{f}}\right)}{\mathrm{W}}
$$

where $\mathrm{V}$ is the volume of EPS solution $(\mathrm{L}), \mathrm{C}_{\mathrm{i}}$ and $\mathrm{C}_{\mathrm{f}}$ are the initial and final metal ion concentrations $\left(\mathrm{mg} \mathrm{L}^{-1}\right)$, respectively. $\mathrm{W}$ is the dry weight of EPS $(\mathrm{g})$.

Furthermore, a dimensionless constant known as separation factor (RL) was calculated in order to test the thermodynamic favorability of adsorption using the following equation:

$$
\mathrm{RL}=\frac{1}{\left(1+\mathrm{bC}_{\mathrm{i}}\right)}
$$

where $b$ is the Langmuir isotherm constant, and $C_{i}$ is the initial metal ion concentration $\left(\mathrm{mg} \mathrm{L}^{-1}\right)$. The RL parameter explains the isotherm as follows: RL $>1$ means unfavorable; RL $=1$ means linear; $0<\mathrm{RL}<1$ means favorable; and RL $=0$ means irreversible adsorption [28,29].

The percentage removal potential of metal ions by EPS was calculated using the following equation [27]:

$$
\text { Removal potential }(\%)=\frac{\text { Initial metal concentration }- \text { Final metal concentration }}{\text { Initial metal concentration }} \times 100
$$

The adsorption of $\mathrm{Cu}(\mathrm{II})$ and $\mathrm{Zn}(\mathrm{II})$ with EPS was also studied using the Freundlich isotherm model which assumes a heterogeneous adsorption surface and active sites with different energies. The isotherm is represented by the equation given below:

$$
\log q=\log K_{f}+n^{-1}\left(\log C_{e}\right)
$$

where $q$ and $C_{e}$ are same as described above. $K_{f}$ is the Freundlich constant which indicates the adsorption capacity $\left(\mathrm{L} \mathrm{g}^{-1}\right)$, and $\mathrm{n}$ represents the exponent known as adsorption intensity. The constants $\mathrm{K}_{\mathrm{f}}\left(\mathrm{L} \mathrm{g}^{-1}\right)$ and $n$ can be determined from the linear plot of $\log q$ versus $\log C_{e}[28,29]$.

\subsection{Statistical Analyses}

The means of replicates were compared by utilizing one-way analysis of variance (ANOVA). The differences of means of each parameter among different sets of conditions were tested by least 
significant difference (LSD) test. Regression analysis was used to determine the degrees of correlation among related factors. Acceptance of the level of statistical significance was done at $5 \%$ level $(p<0.05)$.

\section{Results}

\subsection{Characteristics of EPS}

The FTIR spectroscopy determined the functional groups present on the surface of the EPS [4]. A strong signal at $3378 \mathrm{~cm}^{-1}$ confirmed the existence of an alcoholic and/or carboxylic $\mathrm{OH}$ stretching, and a signal at $2940 \mathrm{~cm}^{-1}$ was attributed to the $\mathrm{CH}$ stretching. The presence of $\mathrm{C} \equiv \mathrm{C}$ was proved by the signal at $2149 \mathrm{~cm}^{-1}$; the conjugated $\mathrm{C}=\mathrm{O}$ or the $\mathrm{H}$ - bonded carboxylic $\mathrm{C}=\mathrm{O}$ stretching was assigned to the signal at $1637 \mathrm{~cm}^{-1}$; and the $777 \mathrm{~cm}^{-1}$ band confirmed the presence of $\mathrm{C}-\mathrm{X}$ (alkyl halides) stretching vibrations. A zeta potential value of $-27.4 \mathrm{mV}$ was obtained for the extracted EPS sample [4]. Both ${ }^{1} \mathrm{H}$ NMR and ${ }^{13} \mathrm{C}$ NMR spectra derived proton signal positions (shielding and deshielding environment) confirmed that the EPS possessed electronegative substituents or groups, unsaturated carbon, $\mathrm{CH}_{2}$-chain and carbonyl groups. For ${ }^{1} \mathrm{H}$ NMR spectrum of the EPS (Figure 1a), the signals obtained from $\delta-1.9 \mathrm{ppm}$ and $\delta-2.3 \mathrm{ppm}$ resembled $\mathrm{CH}_{2}$ protons. Signals from $\delta-2.0 \mathrm{ppm}$ confirmed the presence of $-\mathrm{CH}$ proton attached to vinylic carbon. Signals from $\delta-3.5-3.8 \mathrm{ppm}$ were assigned to the presence of electronegative group deshielding, and signals $\delta-3.9-4.8 \mathrm{ppm}$ confirmed electronegative oxygen coming from the ester functional group. Figure $1 \mathrm{~b}$ represents the ${ }^{13} \mathrm{C}$ NMR spectrum of the EPS. Signals $\delta-27.58-32.20 \mathrm{ppm}$ resembled to- $\mathrm{CH}_{2}$ protonic group. The presence of electronegative group was indicated from signals $\delta-54.78-63.30 \mathrm{ppm}$. Signals $\delta-75.07-80.20 \mathrm{ppm}$ confirmed the presence of unsaturated carbon atoms. The signal of $\delta-104.13 \mathrm{ppm}$ indicated the presence of unsaturation. The presence of carbonyl group was determined by signal $\delta-175.49 \mathrm{ppm}$. Characteristic ${ }^{1} \mathrm{H}$ NMR and ${ }^{13} \mathrm{C}$ NMR signal positions of the EPS are shown in Table 1. The MS-ESI (Mass Spectrometry-Electrospray Ionization) depicts the mass spectra of EPS (Figure 2), and this study further confirmed the molecular weight of the EPS sample while the mass $392 \mathrm{~m} / z$ positive ion mode confirmed the identity of the EPS sample.

Table 1. Characteristic ${ }^{1} \mathrm{H} N M R$ and ${ }^{13} \mathrm{C}$ NMR signal positions with corresponding functional groups of the extracellular polymeric substance (EPS) produced by Bacillus licheniformis strain KX657843 isolated from earthworm (Metaphire posthuma) gut.

\begin{tabular}{cc}
\hline Signal Positions & Functional Groups Present in EPS \\
$\delta-1.9 \mathrm{ppm}$ & $-\mathrm{CH}_{2}$ protons \\
$\delta-2.0 \mathrm{ppm}$ & $-\mathrm{CH}_{2}$ protons \\
$\delta-2.3 \mathrm{ppm}$ & $\mathrm{CH}$ proton attached to vinylic carbon \\
$\delta-3.5-3.8 \mathrm{ppm}$ & presence of electronegative group deshielding \\
$\delta-3.9-4.8 \mathrm{ppm}$ & peak due to electronegative oxygen comes from ester functional group \\
\hline & ${ }^{13} \mathrm{C}$ NMR signal positions \\
$\delta-27.58-32.20 \mathrm{ppm}$ & $-\mathrm{CH}_{2}$ protonic groups \\
$\delta-54.78-63.30 \mathrm{ppm}$ & presence of electronegative group \\
$\delta-75.07-80.20 \mathrm{ppm}$ & presence of unsaturated carbon atoms \\
$\delta-104.13 \mathrm{ppm}$ & presence of unsaturation \\
$\delta-175.49 \mathrm{ppm}$ & presence of carbonyl group \\
\hline
\end{tabular}


(a)

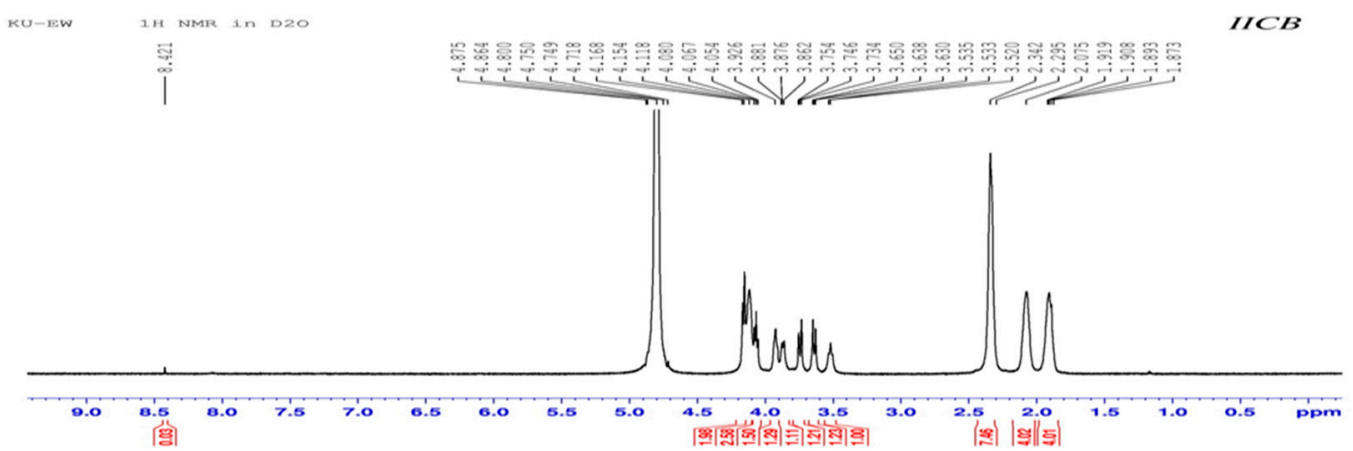

(b)

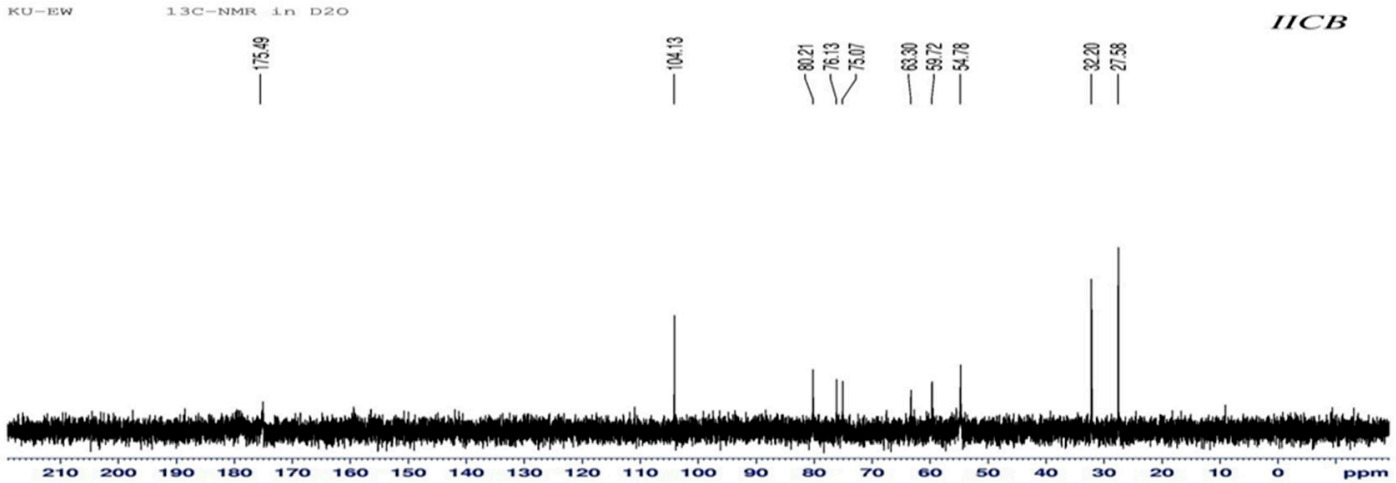

Figure 1. (a) ${ }^{1} \mathrm{H}$ Nuclear Magnetic Resonance (NMR) and (b) ${ }^{13} \mathrm{C}$ NMR signal positions of extracellular polymeric substance (EPS).

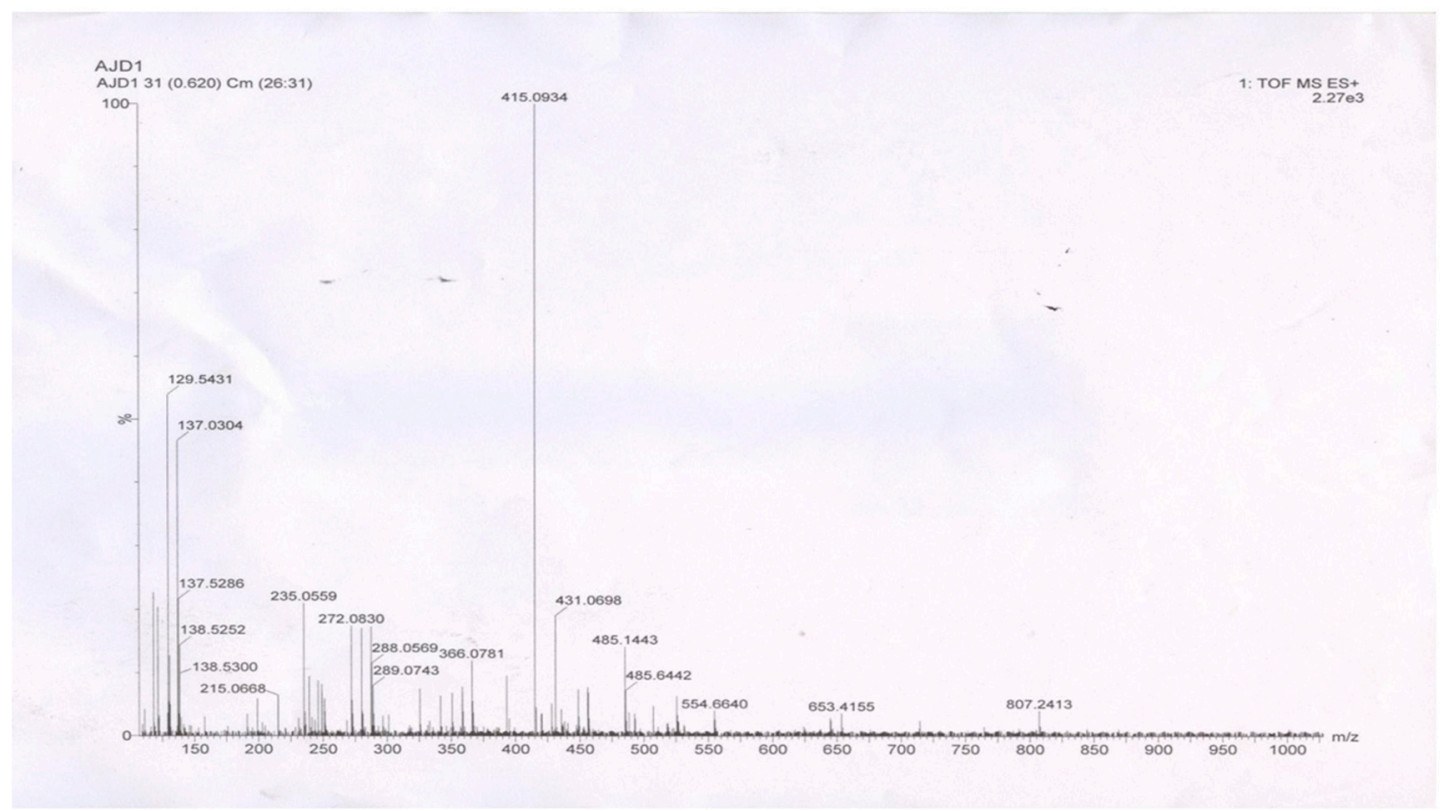

Figure 2. Spectrum of EPS sample.

\subsection{Flocculation Activity of EPS}

The flocculating efficiency obtained with respect to the varying dosage of EPS is shown in Figure 3a. The results showed that maximum flocculation activity (74\%) was obtained at $4 \mathrm{mg} \mathrm{L}^{-1}$ concentration of EPS. This concentration was chosen for the rest of the assays. A further increase in EPS concentration resulted in a decrease in the flocculation activity, and there was a high rate of decline of flocculation activity at EPS concentrations of 18 and $20 \mathrm{mg} \mathrm{L}^{-1}$. 

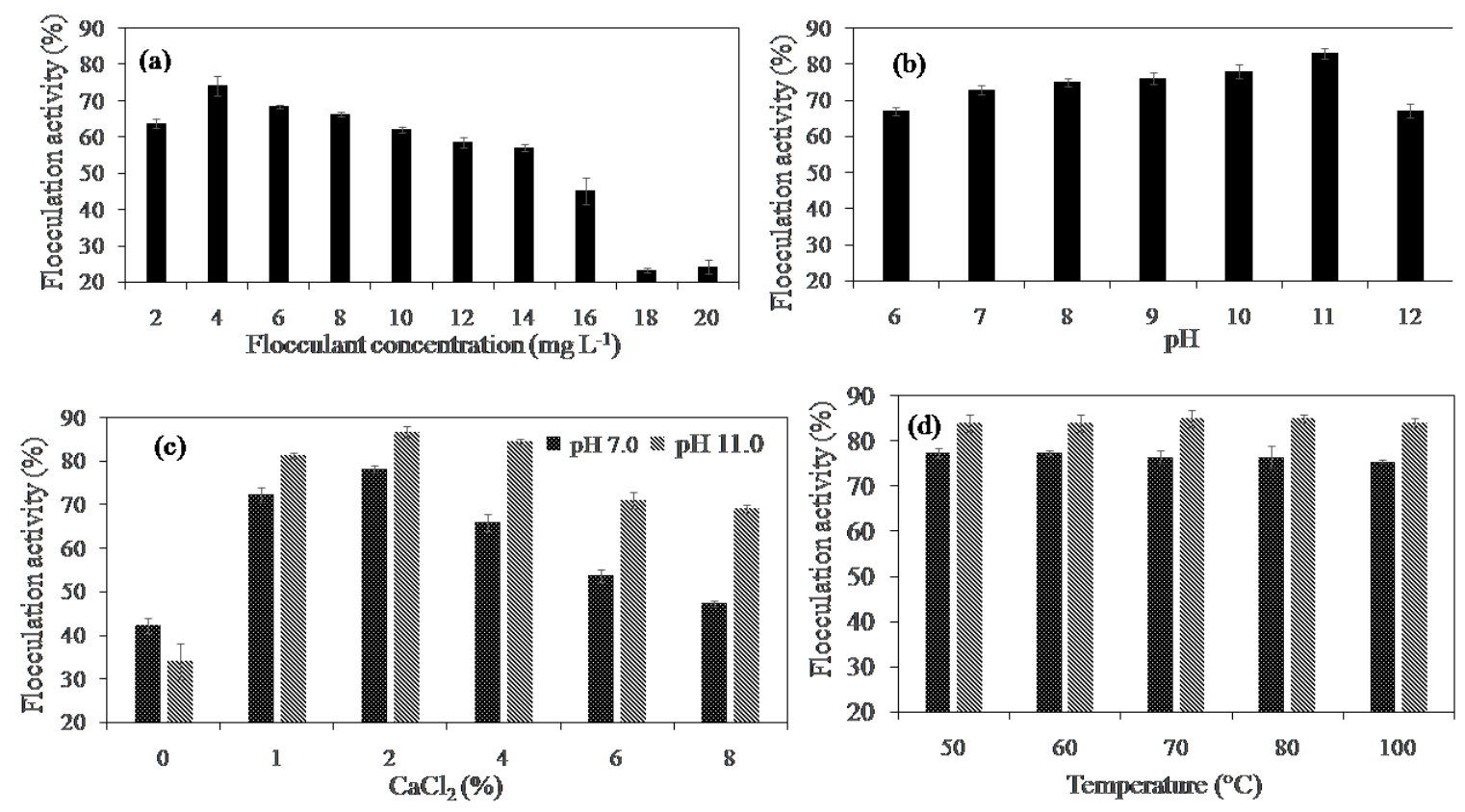

Figure 3. Effect of different controlling factors on flocculation activity performed by Bacillus licheniformis strain KX65783 isolated from earthworm (Metaphire posthuma) gut: (a) varied EPS (flocculant) dosage at a fixed $\mathrm{pH}=7$ and $\mathrm{CaCl}_{2}$ concentration $(2 \%) ;(\mathbf{b})$ varied $\mathrm{pH}$ at a constant EPS concentration $\left(4 \mathrm{mgL}^{-1}\right)$ and $\mathrm{CaCl}_{2}$ concentration (2\%); (c) varied $\mathrm{CaCl}_{2}$ concentration at a fixed EPS concentration $\left(4 \mathrm{mgL}^{-1}\right)$ and $\mathrm{pH} 7$ and $11 ;(\mathbf{d})$ varied temperature at a fixed EPS concentration $\left(4 \mathrm{mgL}^{-1}\right), \mathrm{pH} 7$ and 11, and $\mathrm{CaCl}_{2}$ concentration (2\%). The error bars in the graphs represent the standard deviations.

The effect of $\mathrm{pH}$ on the flocculation activity demonstrated that the EPS failed to show flocculation activity at $\mathrm{pH} \leq 5$. Flocculation activity increased gradually from $\mathrm{pH} 6$ to 11 with no significant variation between $\mathrm{pH} 7-10$. Maximum flocculation activity of $83 \%$ was observed at $\mathrm{pH} 11$ (Figure 3b). The study on the effect of varying dosage of $\mathrm{CaCl}_{2}$ on the flocculation activity showed that $2 \%(0.2 \mathrm{M})$ dosage of $\mathrm{CaCl}_{2}$ possessed the maximum flocculation activity of $72 \%$ and $81 \%$ at $\mathrm{pH} 7$ and 11 , respectively (Figure 3c).

The influence of other ions on flocculation activity (Table 2) showed that $\mathrm{K}^{+}$ions and $\mathrm{Na}^{+}$ions showed lower flocculation activity than the other ions examined, while the best results were observed with $\mathrm{Ca}^{2+}$ ions.

Table 2. Flocculation activity (\%) of the extracted EPS in the presence of different ions. The numerical values indicate the means of replicates $(n=3) \pm$ standard deviations.

\begin{tabular}{cc}
\hline Ions & Flocculation Activity (\%) \\
\hline $\mathrm{CaCl}_{2}$ & $72 \pm 1$ \\
$\mathrm{FeCl}_{3}$ & $51.7 \pm 1.3$ \\
$\mathrm{ZnCl}_{2}$ & $38.5 \pm 1.5$ \\
$\mathrm{CuSO}_{4}$ & $46.5 \pm 1.5$ \\
$\mathrm{NaCl}$ & $12.5 \pm 3.0$ \\
$\mathrm{KCl}$ & $16.5 \pm 1.5$ \\
\hline
\end{tabular}

The effect of temperature on flocculation activity showed that the flocculation activity was retained even after heating the EPS for $30 \mathrm{~min}$ at $10{ }^{\circ} \mathrm{C}$. The flocculation activity was almost constant for all the temperatures both at $\mathrm{pH} 7$ and 11 (Figure 3d). 


\subsection{Adsorption Efficiency of $\mathrm{Cu}(\mathrm{II})$ and $\mathrm{Zn}$ (II) at Varying $\mathrm{pH}$}

The metal adsorption efficiency showed a similar trend for both $\mathrm{Cu}(\mathrm{II})$ and $\mathrm{Zn}$ (II) ions at a concentration of $25 \mathrm{mg} \mathrm{L}^{-1}$. There was an increase in removal potential of metal ions with increasing $\mathrm{pH}$ for both the metal ions. At $\mathrm{pH} 5$, the EPS was able to remove 54 and $42 \%$ of $\mathrm{Cu}$ (II) and $\mathrm{Zn}$ (II), respectively. At pH 8, the EPS could remove 86 and $81 \%$ of $\mathrm{Cu}(\mathrm{II})$ and $\mathrm{Zn}(\mathrm{II})$, respectively (Figure $4 \mathrm{a}$ ). The percentage of sorption of $\mathrm{Cu}$ (II) increased from $54 \%$ at $\mathrm{pH} 5$ to $86 \%$ at $\mathrm{pH} 8$. Similarly, for $\mathrm{Zn}$ (II) the sorption increased from $42 \%$ at $\mathrm{pH} 5$ to $81 \%$ at $\mathrm{pH} 8$.

(a)

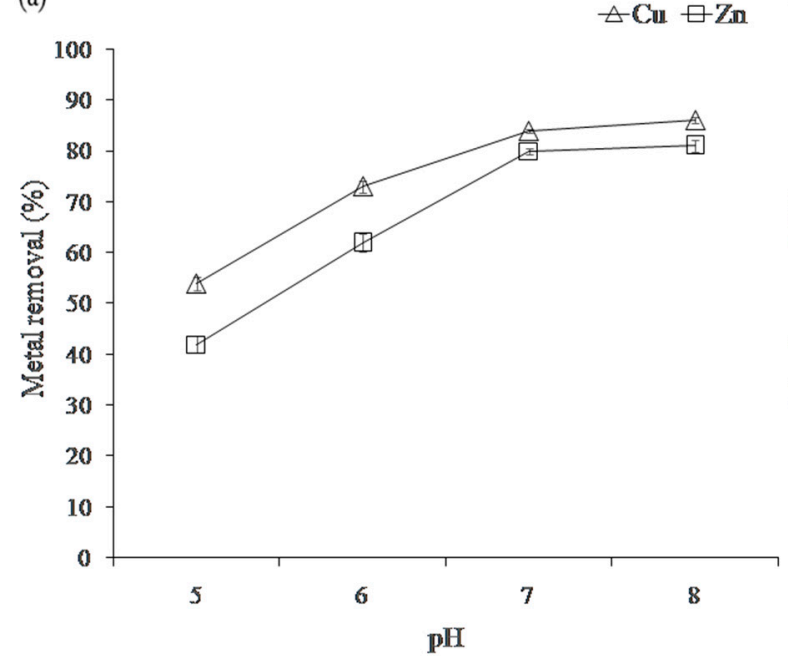

(b)

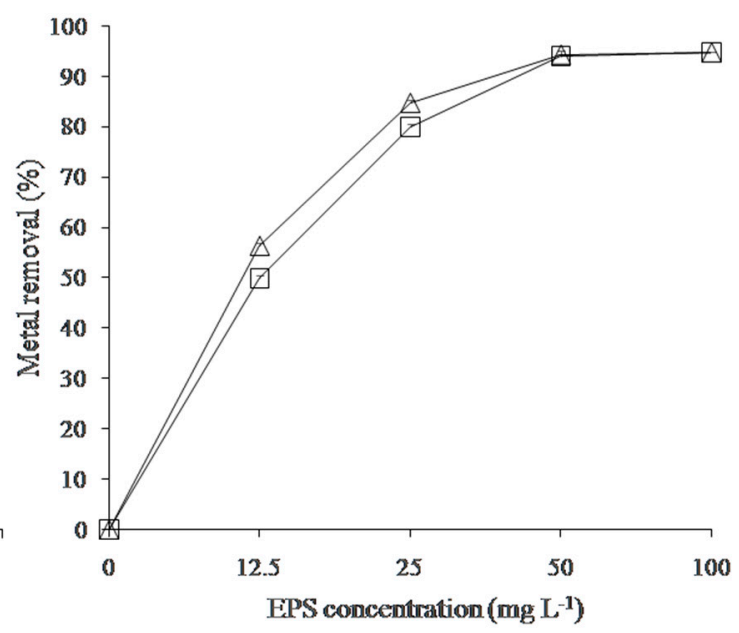

Figure 4. Effect of increasing (a) $\mathrm{pH}$ at a constant concentration of $25 \mathrm{mg} \mathrm{L}^{-1}$ for both metals and EPS and (b) EPS concentration on sorption of metals by EPS at a constant $\mathrm{pH}=7.0$ and a fixed concentration at $25 \mathrm{mg} \mathrm{L}^{-1}$ for both metals. The error bars in the graphs represent respective standard deviation.

\subsection{Adsorption Isotherms}

The effect of EPS dosage on $\mathrm{Cu}(\mathrm{II})$ and $\mathrm{Zn}(\mathrm{II})$ sorption is shown in Figure $4 \mathrm{~b}$. The adsorption of $\mathrm{Cu}$ (II) and $\mathrm{Zn}$ (II) increased as EPS concentration increased from 12.5 to $50 \mathrm{mg} \mathrm{L}^{-1}$. At $100 \mathrm{mg} \mathrm{L}^{-1}$ EPS concentration, the adsorbent got saturated with no further increase in adsorption of the metal ions. The metal removal potential for $\mathrm{Cu}$ (II) increased from 56.4 to $94.4 \%$ when the EPS concentration increased from 12.5 to $50 \mathrm{mg} \mathrm{L}^{-1}$. Similarly, for $\mathrm{Zn}(\mathrm{II})$, the removal potential increased from 50 to $94 \%$ when the EPS concentration increased from 12.5 to $50 \mathrm{mg} \mathrm{L}^{-1}$. The further increase in EPS concentration failed to increase the metal sorption. At $100 \mathrm{mg} \mathrm{L}^{-1}$ EPS concentration, the metal removal potential was $94.8 \%$ for both the metal ions.

The data for adsorption of metal ions by EPS at different concentrations were tested with the Langmuir and Freundlich isotherm models. The correlation coefficients $\left(R^{2}\right)$ of fitting the adsorption data to the Langmuir model were 0.999 for both $\mathrm{Cu}(\mathrm{II})$ and $\mathrm{Zn}(\mathrm{II})$, which showed that the adsorption of metal ions adequately fitted to the Langmuir model. The maximum adsorption capacities $\left(\mathrm{q}_{\mathrm{m}}\right)$ obtained from the Langmuir plots were: $58.82 \mathrm{mg} \mathrm{g}^{-1}$ for $\mathrm{Cu}$ (II) and $52.45 \mathrm{mg} \mathrm{g}^{-1}$ for $\mathrm{Zn}$ (II) (Table 3). The values for the constant $b$ were: $0.27 \mathrm{~L} \mathrm{mg}^{-1}$ for $\mathrm{Cu}(\mathrm{II})$ and $0.29 \mathrm{~L} \mathrm{mg}^{-1}$ for $\mathrm{Zn}$ (II). The correlation coefficients $\left(\mathrm{R}^{2}\right)$ of fitting the adsorption data to the Freundlich model were: 0.95 and 0.97 for $\mathrm{Cu}(\mathrm{II})$ and $\mathrm{Zn}(\mathrm{II})$, respectively. The values for the constants $\mathrm{K}_{\mathrm{f}}$ and $\mathrm{n}^{-1}$ obtained from the Freundlich model fitting were: 12.59 and 2.94 for $\mathrm{Cu}(\mathrm{II})$, and 12.61 and 2.0 for $\mathrm{Zn}(\mathrm{II})$, respectively (Table 3). The $\mathrm{R}^{2}$ values indicated that the Langmuir isotherm model gave a better fitting to the adsorption data than the Freundlich model. The values of $\mathrm{R}_{\mathrm{L}}$ for adsorption of $\mathrm{Cu}(\mathrm{II})$ and $\mathrm{Zn}(\mathrm{II})$ by EPS were 0.13 and 0.12 , respectively. 
Table 3. Langmuir and Freundlich isotherm constants for the sorption of $\mathrm{Cu}(\mathrm{II})$ and $\mathrm{Zn}$ (II) on EPS.

\begin{tabular}{|c|c|c|c|c|c|c|}
\hline \multirow[t]{2}{*}{ Metal Ions } & \multicolumn{3}{|c|}{ Langmuir Isotherm } & \multicolumn{3}{|c|}{ Freundlich Isotherm } \\
\hline & $b\left(\mathrm{~L} \mathrm{mg}^{-1}\right)$ & $q_{m}\left(m g^{-1}\right)$ & $\mathbf{R}^{2}$ & $\mathrm{n}^{-1}$ & $\mathrm{~K}_{\mathrm{f}}$ & $\mathbf{R}^{2}$ \\
\hline $\mathrm{Cu}(\mathrm{II})$ & 0.27 & 58.82 & 0.9993 & 2.94 & 12.59 & 0.952 \\
\hline $\mathrm{Zn}(\mathrm{II})$ & 0.29 & 52.45 & 0.9993 & 2.0 & 12.61 & 0.971 \\
\hline
\end{tabular}

\section{Discussion}

The majority of the influences of earthworms on nutrient cycling and biogeochemical processes of the ecosystem is due to the joint activities of earthworms and the microorganisms selectively activated within their functional domains $[2,30]$. The gut of the earthworm is dominated by high amounts of mucus, plant derived saccharides, organic acids, several denitrification-derived gases such asnitrous oxide $\left(\mathrm{N}_{2} \mathrm{O}\right)$, molecular hydrogen $\left(\mathrm{H}_{2}\right)$ and molecular nitrogen $\left(\mathrm{N}_{2}\right)$. The earthworm gut also experiences increased total organic carbon, nitrogen, and moisture contents which provide an optimal environment for the activation of dormant microbes and support the germination of ingested endospores [3,31].

The earthworm gut environment can influence EPS producing microorganisms [4]. The isolation of an EPS producing bacterial strain Bacillus licheniformis with accession number KX65784 from the earthworm gut (Metaphire posthuma) has been reported earlier [4,20]. The isolated strain was unique in producing EPS only in the presence of L-asparagine monohydrate and maximum EPS yield was observed when sucrose was the carbon substrate [4]. The phenotypic and genotypic characterization, optimal conditions for growth and EPS production of the strain isolated from the earthworm gut were also reported earlier [4]. The current study focuses on the application aspect of the EPS produced by the above bacterial strain.

The FTIR and NMR analyses act as powerful tools for studying and speculating several functional groups [32], carbohydrate compositions and structure of complex substances in biomolecules such as EPS. The ${ }^{1} \mathrm{H}$ NMR and ${ }^{13} \mathrm{C}$ NMR spectra (Figure $1 \mathrm{a}, \mathrm{b}$ ) confirmed that the isolated EPS possessed electronegative substituents or groups, unsaturated carbon, $\mathrm{CH}_{2}$-chain and carbonyl groups. The signals from $\delta-1.9 \mathrm{ppm}$ and $\delta-2.3 \mathrm{ppm}$ resembling $-\mathrm{CH}_{2}$ protons, and signals from $\delta-3.5-3.8 \mathrm{ppm}$ indicating the presence of electronegative group deshielding were in accordance to earlier report [26]. Previous authors [26] similarly reported a strong signal at $\delta-1.87 \mathrm{ppm}$ indicating the presence of alkyl $-\mathrm{CH}_{2}$ protons, while the $\delta-3.5-3.8 \mathrm{ppm}$ signals indicated the presence of electronegative group. The FTIR analysis showed that majority of the functional groups in the isolated EPS belonged to alkanes, alkynes, carboxylic and alcoholic groups. The results of FTIR and NMR analyses obtained by previous studies [33-35] were in conformity with our results. The EPS composition consisted of carbohydrates with some amounts of proteins and sugar acids, and also traces of nucleic acids. Mass spectra (Figure 2) revealed the mass of the extracted EPS. The anionic nature of the EPS extracted from the gut of the earthworm was confirmed from the zeta potential value [4].

The biological functioning of EPS and EPS producing bacteria are determined by the occurrence of the charged (positive or negative) functional groups. The presence of a significant quantity of negatively charged functional groups, such as carboxyls and hydroxyls, in the EPS evident from the NMR and IR studies indicated a high carbohydrate to protein ratio in the biomolecules. This feature of the EPS might offer a vast promise in the removal and remediation of heavy metals from polluted environments by this EPS $[23,28,36]$.

Microbial EPS are an emerging group of bioflocculants that can potentially replace synthetic flocculants in various applications. A large number of extracellular biopolymeric flocculants have been isolated from diverse groups of microorganisms, but their chemical compositions and activities differ greatly $[11,37]$. An important parameter in flocculation is the dosage of the applied flocculant. An insufficient dose would affect the bridging mechanism and formation of flocs, while an overdose would inhibit sedimentation of suspended particles and cause high viscosity in the flocculating 
medium [38]. In the present study, the bioflocculant showed a flocculation efficiency of $74 \%$ at $4 \mathrm{mg}$ $\mathrm{L}^{-1}$ concentration of EPS (Figure 3a). Different microbial strains have different flocculation efficiency at different concentrations. The ability of Bacillus licheniformis strains to produce bioflocculant has been reported $[39,40]$. Studies showed that bioflocculant from the strain Bacillus licheniformis produced $700 \mathrm{U} \mathrm{mL}^{-1}$ flocculation activities after cultivation at $37^{\circ} \mathrm{C}$ for $48 \mathrm{~h} \mathrm{[40].} \mathrm{Another} \mathrm{study} \mathrm{on} \mathrm{Bacillus} \mathrm{sp.}$ showed that this strain produced a maximum of $83.45 \%$ flocculation activity at $12 \mathrm{mg} \mathrm{L}^{-1}$ flocculant concentration [11]. Another essential parameter for flocculation is the system $\mathrm{pH}$. In the present study, the flocculation efficiency showed pronounced activity in a basic medium, with the maximum activity at pH 11 (Figure 3b). Bioflocculants exhibit varying degree of electrical states at varying $\mathrm{pH}$. Alteration of $\mathrm{pH}$ alters the charge status on bioflocculant which in turn alters the surface characteristics of suspended materials. This results in a change of the flocculation ability of the flocculants [41,42]. The present study found conformity with other reports where alkaline $\mathrm{pH}$ favored bioflocculation of suspended particles $[37,38,43]$. The present study failed to flocculate the suspended kaolin particles at an acidic $\mathrm{pH}$ below 6 . The increase in flocculation activity at higher $\mathrm{pH}$ than at lower $\mathrm{pH}$ could be due to the fact that at higher $\mathrm{pH}$ the $\mathrm{OH}^{-}$ions might disrupt the formed complexes between kaolin and the bioflocculant, while lower $\mathrm{pH}$ might cause the adsorption of $\mathrm{H}^{+}$ions by both the bioflocculant and kaolin particles leading to reduced flocculation activity [44]. These results were supported by other reports where bioflocculant produced by Bacillus megaterium strain caused flocculation in the $\mathrm{pH}$ range of 7 to 12 with maximum flocculation at $\mathrm{pH} 9$ and acidic $\mathrm{pH}$ inhibited flocculation [45].

Another important parameter for flocculation is the presence of cations. Cations neutralize and stabilize negative charges of functional groups of both kaolin particles and the bioflocculant [38]. In the present study, the effect of varying concentrations of $\mathrm{CaCl}_{2}$ on the flocculation activity showed that maximum activity was observed at $2 \%$ salt concentration (Figure $3 \mathrm{c}$ ). Here too, the flocculation activity was better at $\mathrm{pH} 11$ than low $\mathrm{pH}$ values. The flocculation activities against various cations are shown in Table 2 indicating that flocculation efficiency was more in the case of divalent cations. The maximum value was for $\mathrm{Ca}^{2+}$ ions. Divalent cations neutralize negative charges on both the kaolin particles and bioflocculant, which minimizes the repulsive forces, thereby enhancing adsorption of bioflocculant onto the surface of the kaolin clay leading to agglomeration of flocs and sedimentation of the suspended particles [45]. This result was supported by other reports where divalent cations enhanced flocculation while monovalent ions failed to cause effective flocculation $[37,38]$. In spite of being a trivalent cation, $\mathrm{Fe}^{3+}$ failed to increase the bioflocculation activity in the present study. This could be due to the fact that there was an antagonistic effect between $\mathrm{Fe}^{3+}$ and the bioflocculant. $\mathrm{Fe}^{3+}$ could have caused an alteration in the charge of kaolin surfaces and at the same time covered the reactive adsorption sites. Consequently, a competition between the positively charged particles and the adsorption sites might have occurred causing an antagonistic effect of $\mathrm{Fe}^{3+}$ ions and subsequent decrease in flocculation activity [46]. The result was in accordance with other reports [47] where $\mathrm{Fe}^{3+}$ showed least or no flocculation activity.

The experiment on the effect of temperature on the flocculation ability of EPS showed that the EPS was thermally stable (Figure 3d). Flocculation activity was retained even when the EPS was exposed to a temperature of $100{ }^{\circ} \mathrm{C}$ for $30 \mathrm{~min}$. The result was akin to other reports where thermal stability of EPS and retention of flocculation activity were shown $[38,40,48]$. The flocculation activity was higher at $\mathrm{pH}$ 11 than at $\mathrm{pH} 7$ even at a varying temperature. Reports suggested that flocculants rich in carbohydrate backbone showed greater thermal stability than those of protein and nucleic acid backbones [38]. The FTIR and NMR analyses of the EPS in our studies showed the presence of carbohydrate in the EPS backbone, thus confirming the thermal stability of the EPS.

Utilizing EPS produced by bacteria in metal adsorption is one of the most profoundly driven approaches in metal remediation [18]. One of the important parameters for metal adsorption by bacterial EPS is the initial $\mathrm{pH}$ of the solution. The $\mathrm{pH}$ not only affects the speciation of metal ions in the solution, but also influences the surface charges and dissociation of binding sites of the biosorbent [15]. 
In the present study, the adsorption was low for both the metal ions at $\mathrm{pH} 5$, while the adsorption increased with an increase of $\mathrm{pH}$ values from 5 to 8 (Figure 4a).

A low $\mathrm{pH}$ is responsible for raising the concentration of hydrogen ions in the solution, which increases the positive charges of functional groups present on the biosorbent surfaces. As a result, an electrostatic repulsion can occur between the positively charged functional groups and the positively charged metal ions. Additionally, a competition between metal ions and hydrogen ions for binding sites on EPS surfaces can also arise, which would result in fewer binding sites available on the surface of EPS to bind the metal ions. At high $\mathrm{pH}$ on the other hand, the biosorbent surface becomes negatively charged due to deprotonation of metal binding sites, and consequently the metal ions get electrostatically attracted and adsorbed on the surface $[28,36]$. Carboxylic groups play an important role in the $\mathrm{pH}$-responsive protonation-deprotonation reactions as discussed above and participate in the complexation of metal ions resulting in the best adsorption performance at $\mathrm{pH} 7$ [49]. The EPS isolated in the present study showed the presence of carboxyl groups [4], which might be the reason behind the better adsorption of metal ions at $\mathrm{pH} 7$ by the isolated EPS. There are reports showing a constant adsorption of $\mathrm{Cu}$ (II) from $\mathrm{pH}$ 1-9, while for $\mathrm{Zn}$ (II) there was an initial increase in adsorption at initial increase in $\mathrm{pH}$ from 1-3 after which up to $\mathrm{pH} 9$ there was a constant adsorption without any change [36]. Similarly, reports showed that there was a constant increase in the amount of $\mathrm{Cu}$ (II) adsorbed by EPS from $0.09 \mathrm{mmol} \mathrm{g}^{-1}$ EPS at $\mathrm{pH} 3.0$ to $0.37 \mathrm{mmol} \mathrm{g}^{-1}$ EPS at $\mathrm{pH} 7.0$ [28].

Another important parameter for metal sorption by bacterial EPS is the initial concentration of the EPS used. The capacity of sorption of metal ions by EPS in this study reached a constant value when the concentration of EPS was $50 \mathrm{mg} \mathrm{L}^{-1}$ and it remained constant even at $100 \mathrm{mg} \mathrm{L}^{-1}$. This can be due to the fact that, an increase of the biosorbent dosage resulted in an increase in the number of sites available for adsorption at lower EPS concentrations. A higher EPS concentration, on the other hand, led to a saturation of binding sites on the biosorbent surface. Higher concentration of EPS could have resulted in interference between the binding sites themselves. Another reason which led to the formation of the plateau region as seen in Figure $4 \mathrm{~b}$ could be due to the fact that there was an insufficient number of metal ions in the solution with respect to the number of available binding sites [28,29,50]. A previous study [28] showed that an increase in EPS concentration from 26 to $135 \mathrm{mg}$ $\mathrm{L}^{-1}$ resulted in the increase in adsorption of $\mathrm{Cu}(\mathrm{II})$, while further increase in EPS concentration failed to increase the adsorption of $\mathrm{Cu}$ (II). Similarly, reports showed an increase in adsorption of metal ions with initial increase in EPS concentration while further increase failed to increase the adsorption of metal ions $[29,36]$.

Optimization of adsorption systems and determination of the efficiency of adsorption is accomplished by equilibrium adsorption isotherms. The Langmuir isotherm postulates the monolayer adsorption on homogenous surfaces, and Freundlich isotherm assumes the multilayer formation on heterogenous surfaces [28]. The model parameter values obtained (Table 3) indicated that the adsorption of metal ions onto the EPS synthesized by Bacillus licheniformis isolated from the earthworm gut fitted to the Langmuir model better than the Freundlich model. These results indicated a monolayer adsorption mechanism taking place between EPS and the metal ions, in accordance to the Langmuir model $[15,28,36]$.

\section{Conclusions}

The EPS derived from Bacillus licheniformis KX657843 isolated from the earthworm Metaphire posthuma showed potential flocculating and metal sorption properties. The zeta potential, FTIR and NMR analyses confirmed the polyanionic nature of the EPS. The majority of components of the extracted EPS were carbohydrates, proteins, sugars and nucleic acids. The EPS also possessed electronegative groups, unsaturated carbon, $\mathrm{CH}_{2}$-chain and carbonyl groups. The ability to remove heavy metal $\mathrm{Cu}$ (II) and $\mathrm{Zn}$ (II) from aqueous solutions implied that the EPS could be used as an effective adsorbent for heavy metal sorption in aqueous solutions. The study also confirmed that the adsorption of metal ions by the EPS was in accordance with the Langmuir isotherm model. Thus, the present study 
demonstrated that microbial EPS might find applications in addressing multifarious environmental problems including heavy metal remediation, water/wastewater treatment and industrial waste treatment. The emerging potentials of earthworm gut microflora as an environmental management tool warrant future research investigations.

Supplementary Materials: The following are available online at http://www.mdpi.com/2076-3417/10/1/349/s1, Figure S1: The isolation of the bacteria with a characteristic slimy, mucoid phenotypic nature from the gut of the earthworm Metaphire posthuma, Figure S2. Atomic absorption spectroscopy (AAS) standard curve for metals $\mathrm{Cu}$ (II) and $\mathrm{Zn}(\mathrm{II})$.

Author Contributions: Conceptualization: J.K.B.; methodology: J.K.B., A.B. and D.S.; software: A.B. and J.K.B.; experiments, A.B.; resources: J.K.B., A.B. and S.K.S.; data curation: J.K.B., B.S. and A.B.; original draft preparation: J.K.B. and A.B.; critical review and editing: J.K.B., B.S., D.S., S.K.S., M.R. and M.V.; supervision: J.K.B.; project administration: J.K.B.; funding acquisition: A.B. and J.K.B. All authors have read and agreed to the published version of the manuscript.

Funding: The authors acknowledge the financial assistance received from Department of Science and Technology (DST), Government of India. A. Banerjee was awarded an INSPIRE Fellowship (Code No.: 1F131101) for conducting her doctoral research under the guidance of J. K. Biswas.

Acknowledgments: The authors acknowledge the instrumental and other infrastructural support provided by DST PURSE, University of Kalyani, for the present study.

Conflicts of Interest: The authors declare no conflict of interest.

\section{References}

1. Wurst, S.; Sonnemann, I.; Zaller, J.G. Soil macro-invertebrates: Their impact on plants and associated aboveground communities in temperate regions. In Aboveground-Belowground Community Ecology Ecological Studies (Analysis and Synthesis); Ohgushi, T., Wurst, S., Johnson, S., Eds.; Springer: Cham, Switzerland, 2018; Volume 234.

2. Leon, Y.S.; Wise, D.H.; Perez, J.L.; Norby, R.J.; James, S.W.; Gonzalez-Meler, M.A. Endogeic earthworm densities increase in response to higher fine-root production in a forest exposed to elevated $\mathrm{CO}_{2}$. Soil Biol. Biochem. 2018, 122, 31-38. [CrossRef]

3. Meier, A.B.; Hunger, S.; Drake, H.L. Differential engagement of fermentative taxa in gut contents of the earthworm Lumbricusterrestris. Appl. Environ. Microbiol. 2017. [CrossRef] [PubMed]

4. Biswas, J.K.; Banerjee, A.; Majumder, S.; Bolan, N.; Seshadri, B.; Dash, M.C. New extracellular polymeric substance producing enteric bacterium from earthworm, Metaphire posthuma: Modulation through culture conditions. Proc. Zool. Soc. 2017. [CrossRef]

5. Shi, Y.; Huang, J.; Zeng, G.; Gu, Y.; Chen, Y.; Hu, Y.; Tang, B.; Zhou, J.; Yang, Y.; Shi, L. Exploiting extracellular polymeric substances (EPS) controlling strategies for performance enhancement of biological wastewater treatments: An overview. Chemosphere 2017, 180, 396-411. [CrossRef]

6. Pawar, S.T.; Bhosale, A.A.; Gawade, T.B.; Nale, T.R. Isolation, screening and optimization of exopolysaccharide producing bacterium from saline soil. J. Microbiol. Biotechnol. Res. 2013, 3, 4-31.

7. Comte, S.; Guibaud, G.; Baudu, M. Biosorption properties of extracellular polymeric substances (EPS) towards $\mathrm{Cd}$ : $\mathrm{Cu}$ and $\mathrm{Pb}$ for different $\mathrm{pH}$ values. J. Hazard. Mater. 2008, 151, 185-193. [CrossRef]

8. Caruso, C.; Rizzo, C.; Mangano, S.; Poli, A.; Donato, P.D.; Finore, I.; Nicolaus, B.; Marco, G.D.; Michaud, L.; Guidice, A.L. Production and biotechnological potentialities of extracellular polymeric substances 2 from sponge-associated Antarctic bacteria. Appl. Environ. Microbiol. 2017. [CrossRef]

9. Drakou, E.M.; Amorium, C.L.; Castro, P.M.L.; Panagiotou, F.; Vyrides, I. Wastewater valorization by pure bacterial cultures to extracellular polymeric substances (EPS) with high emulsifying potential and flocculation activities. Waste Biomass Valorization 2017. [CrossRef]

10. Xiao, R.; Yang, X.; Li, M.; Li, X.; Wei, Y.; Cao, M.; Ragauskas, A.; Thies, M.; Ding, J.; Zheng, Y. Investigation of composition, structure and bioactivity of extracellular polymeric substances from original and stress-induced strains of Thraustochytrium striatum. Carbohydr. Polym. 2018. [CrossRef]

11. Busi, S.; Karuganti, S.; Rajkumari, J.; Paramanandham, P.; Pattnaik, S. Sludge settling and algal flocculation activity of extracellular polymeric substance (EPS) derived from Bacillus cereus SK. Water Environ. J. 2017, 31, 97-104. [CrossRef] 
12. Pakdel, P.M.; Peighambardoust, S.J. A review on acrylic based hydrogels and their applications in wastewater treatment. J. Environ. Manag. 2018, 217, 123-143. [CrossRef] [PubMed]

13. Pennisi, M.; Malaguarnera, G.; Puglisi, V.; Vinciguerra, L.; Vacante, M.; Malaguarnera, M. Neurotoxicity of acrylamide in exposed workers. Int. J. Environ. Res. Public Health 2013, 10, 3843-3854. [CrossRef] [PubMed]

14. Sun, P.; Zhang, J.; Esquivel-Elizondo, S.; Ma, L.; Wu, Y. Uncovering the flocculating potential of extracellular polymeric substances produced by periphytic biofilms. Bioresour. Technol. 2017. [CrossRef] [PubMed]

15. Dobrowolski, R.; Szczes, A.; Czemierska, M.; Jarosz-Wikołazka, A. (2017) Studies of cadmium(II), lead(II), nickel(II), cobalt(II) and chromium(VI) sorption on extracellular polymeric substances produced by Rhodococcus opacus and Rhodococcus rhodochrous. Bioresour. Technol. 2017, 225, 113-120. [CrossRef]

16. Lakherwal, D. Adsorption of heavy metals: A review. Int. J. Environ. Res. Dev. 2014, 4, 41-48.

17. Biswas, J.K.; Mondal, M.; Rinklebe, J.; Sarkar, S.K.; Chaudhuri, P.; Rai, M.; Shaheen, S.M.; Song, H.; Rizwan, M. Multi-metal resistance and plant growth promotion potential of a waste water bacterium Pseudomonas aeruginosa and its synergistic benefits. Environ. Geochem. Health 2017, 39, 1583-1593. [CrossRef]

18. Gupta, P.; Diwan, B. Bacterial exopolysaccharide mediated heavy metal removal: A review on biosynthesis, mechanism and remediation strategies. Biotechnol. Rep. 2017, 13, 58-71. [CrossRef]

19. Osyczka, P.; Rola, K. Integrity of lichen cell membranes as an indicator of heavy-metal pollution levels in soil. Ecotoxicol. Environ. Saf. 2019, 174, 26-34. [CrossRef]

20. Biswas, J.K.; Banerjee, A.; Rai, M.K.; Rinklebe, J.; Shaheen, S.M.; Sarkar, S.K.; Dash, M.C.; Kaviraj, A.; Langer, U.; Song, H.; et al. Exploring potential applications of a novel extracellular polymeric substance synthesizing bacterium (Bacillus licheniformis) isolated from gut contents of earthworm (Metaphire posthuma) in environmental remediation. Biodegradation 2018. [CrossRef]

21. Ce'rantola, S.; Boune'ry, J.D.; Segonds, C.; Marty, N. Exopolysaccharide production by mucoid and non mucoid strains of Burkholderia cepacia. FEMS Microbiol. Lett. 2000, 185, 243-246. [CrossRef]

22. Cao, Y.; Weia, X.; Cai, P.; Huang, Q.; Rong, X.; Liang, W. Preferential adsorption of extracellular polymeric substances from bacteria on clay minerals and iron oxide. Colloids Surf. B Biointerfaces 2011, 83, 122-127. [CrossRef] [PubMed]

23. Batool, R.; Yrjala, K.; Shaukat, K.; Jamil, N.; Hasnain, S. Production of EPS under Cr(VI) challenge in two indigenous bacteria isolated from a tannery effluent. J. Basic Microbiol. 2015, 55, 1064-1074. [CrossRef] [PubMed]

24. Hunter, R.J. Zeta Potential in Colloids Science: Principles and Applications; Academic Press: New York, NY, USA, 1981.

25. Bala Subramanian, S.; Yan, S.; Tyagi, R.D.; Surampalli, R.Y. Extracellular polymeric substances (EPS) producing bacterial strains of municipal wastewater sludge: Isolation, molecular identification, EPS characterization and performance for sludge settling and dewatering. Water Res. 2010, 44, 2253-2266. [CrossRef] [PubMed]

26. Sathiyanarayanan, G.; Kiran, G.S.; Selvin, J. Synthesis of silver nanoparticles by polysaccharide bioflocculant produced from marine Bacillus subtilis MSBN17. Colloids Surf. B. 2013, 102, 13-20. [CrossRef]

27. Sathiyanarayanan, G.; Bhatia, S.K.; Kim, H.J.; Kim, J.H.; Jeon, J.M.; Kim, Y.G.; Park, S.H.; Lee, S.H.; Lee, Y.K.; Yang, Y.H. Metal removal and reduction potential of an exopolysaccharide produced by Arctic psychrotrophic bacterium Pseudomonas sp. PAMC 28620. R. Soc. Chem. 2016. [CrossRef]

28. Yin, Y.; Hu, Y.; Xiong, F. Sorption of $\mathrm{Cu}(\mathrm{II})$ and $\mathrm{Cd}(\mathrm{II})$ by extracellular polymeric substances (EPS) from Aspergillus fumigatus. Int. Biodeterior. Biodegrad. 2011, 65, 1012-1018. [CrossRef]

29. Zhang, Z.; Cai, R.; Zhang, W.; Fu, Y.; Jiao, N. A novel exopolysaccharide with metal adsorption capacity produced by a marine bacterium Alteromonas sp. JL2810. Mar. Drugs 2017, 15, 175. [CrossRef]

30. Zhang, J.; Sugir, M.E.; Li, Y.; Yuan, L.; Zhou, M.; Lv, P.; Yu, Z.; Wang, L.; Zhou, D. Effects of vermicomposting on the main chemical properties and bioavailability of $\mathrm{Cd} / \mathrm{Zn}$ in pure sludge. Environ. Sci. Pollut. Res. 2019. [CrossRef]

31. Pathma, J.; Sakthivel, N. Microbial diversity of vermicompost bacteria that exhibit useful agricultural traits and waste management potential. Springerplus 2012. [CrossRef]

32. Liu, P.; Zhou, W.; Cui, H.; Tan, J.; Cao, S. Structural characteristics of humic substances in buried ancient paddy soils as revealed by ${ }^{13} \mathrm{C}$ NMR spectroscopy. Environ. Geochem. Health 2019. [CrossRef]

33. Antonio, S.; Concetta, G.; Valeria, L.; Teresa, L.M.; Gianluca, A.; Annarita, P.; Barbara, N. A novel EPS-producing strain of Bacillus licheniformis isolated from a shallow vent off Panarea island (Italy). Curr. Microbiol. 2013, 67, 27-29. 
34. Nambiar, R.B.; Sellamuthu, P.S.; Perumal, A.B.; Sadiku, E.R.; Phiri, G.; Jayaramudu, J. Characterization of an exopolysaccharide produced by Lactobacillus plantarum HM47 isolated from Human breast milk. Process Biochem. 2018. [CrossRef]

35. Yang, Y.; Feng, F.; Zhou, Q.; Zhao, F.; Du, R.; Zhou, Z.; Han, Y. Isolation, purification and characterization of exopolysaccharide produced by Leuconostoc pseudomesenteroides YF32 from soybean paste. Int. J. Biol. Macromol. 2017. [CrossRef] [PubMed]

36. Li, H.; Wei, M.; Min, W.; Gao, Y.; Liu, X.; Liu, J. Removal of heavy metal ions in aqueous solution by exopolysaccharides from Atheliarolfsii. Biocatal. Agric. Biotechnol. 2016. [CrossRef]

37. Zhu, C.; Chen, C.; Zhao, L.; Zhang, Y.; Yang, J.; Song, L.; Yang, S. Bioflocculant produced by Chlamydomonas reinhardtii. J. Appl. Phycol. 2012, 24, 1245-1251. [CrossRef]

38. Agunbiade, M.O.; Heerden, E.V.; Pohl, C.H.; Ashafa, A.T. Flocculating performance of a bioflocculant produced by Arthrobacter humicola in sewage waste water treatment. BMC Biotechnol. 2017. [CrossRef]

39. Shih, I.L.; Van, L.C.; Lin, H.G.; Chang, Y.N. Production of biopolymer flocculant from Bacillus licheniformis and its flocculation properties. Bioresour. Technol. 2001, 78, 267-272. [CrossRef]

40. Xiong, Y.; Wang, Y.; Yu, Y.; Li, Q.; Wang, H.; Chen, R.; He, N. Production and characterization of a novel bioflocculant from Bacillus licheniformis. Appl. Environ. Microbiol. 2010, 76, 2778-2782. [CrossRef]

41. Zhang, H.; Lin, Z. Microbial flocculant and its application in environmental protection. J. Environ. Sci. 1999, 11, 1-12.

42. Pan, Y.Z.; Shi, B.; Zhang, Y. Research on flocculation property of bioflocculant PG. a21 Ca. Mod. Appl. Sci. 2009, 3, 106-112. [CrossRef]

43. Li, Y.; Li, Q.; Hao, D.; Hu, Z.; Song, D.; Yang, M. Characterization and flocculation mechanism of an alkali-activated polysaccharide flocculant from Arthrobacter sp. B4. Bioresour. Technol. 2014, 170, 574-577. [CrossRef] [PubMed]

44. Ma, F.; Zheng, L.N.; Chi, Y. Applications of biological flocculants (BFs) for coagulation treatment in water purification: Turbidity elimination. Chem. Biochem. Eng. Q. 2008, 22, 321-326.

45. Zheng, Y.; Ye, Z.L.; Fang, X.L.; Li, Y.H.; Cai, W.M. Production and characteristics of a bioflocculant produced by Bacillus sp. F19. Bioresour. Technol. 2008, 99, 7686-7691. [CrossRef] [PubMed]

46. Gong, W.; Wang, S.; Sun, X.; Liu, X.; Yue, Q.; Gao, B. Bioflocculant production by culture of Serratia ficaria and its application in waste water treatment. Bioresour. Technol. 2008, 99, 4668-4674. [CrossRef] [PubMed]

47. Sekelwa, C.; Anthony, U.M.; Vuyani, M.L.; Anthony, O.I. Characterization of a thermostable polysaccharide bioflocculant produced by Virgi bacillus species isolated from Algoa bay. Afr. J. Microbiol. Res. 2013, 7, 2925-2938.

48. Wang, L.; Ma, F.; Lee, D.; Wang, A.; Ren, N. Bioflocculants from hydrolysates of corns stover using isolated strain Ochrobactium ciceri W2. Bioresour. Technol. 2013, 145, 259-263. [CrossRef]

49. Guibaud, G.; Comte, S.; Bordas, F.; Dupuy, S.; Baudu, M. Comparison of the complexation potential of extracellular polymeric substances (EPS), extracted from activated sludges and produced by pure bacteria strains, for cadmium, lead and nickel. Chemosphere 2005, 59, 629-638. [CrossRef]

50. Salehizadeh, H.; Shojaosadati, S.A. Removal of metal ions from aqueous solution by polysaccharide produced from Bacillus firmus. Water Res. 2003, 37, 4231-4235. [CrossRef]

(C) 2020 by the authors. Licensee MDPI, Basel, Switzerland. This article is an open access article distributed under the terms and conditions of the Creative Commons Attribution (CC BY) license (http://creativecommons.org/licenses/by/4.0/). 